\title{
Sociala processer avgör hur elever reagerar som åskådare vid mobbning
}

\author{
Camilla Forsberg
}

Institutionen för beteendevetenskap och lärande, Pedagogik och didaktik, Linköpings universitet

När elever i fjärde till sjunde klass intervjuas om hur de reagerar som åskådare till mobbning framkommer att sociala processer såsom vad som räknas som mobbning, sociala relationer och skuldbeläggande av den utsatta påverkar om de hjälper till eller inte.

Mobbning fortsätter att vara ett problem i svenska skolor. Elevers perspektiv betonas ofta som viktigt i det förebyggande arbetet mot mobbning, men trots detta har forskningen om hur elever själva reagerar på mobbning varit eftersatt. I en studie av elevers perspektiv på mobbning undersöktes hur elever själva resonerar kring att ingripa som åskådare till mobbning.

I studien deltog 43 elever från fjärde till sjunde klass i Sverige. Eleverna kom från fem olika skolor belägna i olika geografiska områden. Dessutom deltog 46 elever från fjärde till sjunde klass från två skolor i USA. Eleverna intervjuades individuellt och fick frågor som: Vad är mobbning? Skulle du kunna berätta om en mobbningssituation du sett eller hört om och hur reagerade du? Hur reagerande andra när detta hände?

Resultaten som helhet är publicerade i två artiklar i Research Papers in Education (Forsberg et al., 2016; Forsberg, Thornberg \& Samuelsson, 2014).

\section{Åskådarroller definieras i den sociala situationen}

Det var genomgående tydligt att eleverna ville förklara sitt sätt att reagera som åskådare med att lyfta fram den sociala situationens betydelse. Beroende på hur eleverna definierade den sociala situationen kunde någon av följande tre åskådarroller användas:

1. den ingripande som hjälper till

2. den passiva, eller

3. den som går med i mobbningen.

De här typerna av åskådarroller har identifierats i tidigare forskning (Salmivalli, 1999).

Vad den här studien bidrar med att belysa är hur eleverna förklarar vad som påverkar deras sätt att reagera som åskådare.

Utifrån hur eleverna resonerade framträdde tre förklaringar till deras val av åskådarroll: bedömning av hjälpbehov; kamratnormer och sociala hierarkier och andras ansvar.

\section{Bedömning av hjälpbehov}

Eleverna förklarade sitt sätt att reagera som åskådare som beroende av hur de bedömde situationens allvar. Det var viktigt att ingripa i rätt situationer och inte i sådana som kunde vara skoj. En tydlig skiljelinje gick här mellan situationer som innehöll fysiskt våld och situationer som innehöll verbala kränkningar eller utfrysning. 


\section{Venue}

Vol 6 Nr 2 (2017): Tema: Mobbning

Av Forskare

Fysiskt våld var alltid allvarligt och då behövdes alltid hjälp. Verbala kränkningar eller utfrysning bedömdes inte alltid som allvarligt och då fanns inte heller samma hjälpbehov. Om en situation inte uppfattades som allvarlig uttryckte eleverna att de mer troligen skulle förbli passiva och inte ingripa. Den passiva åskådarrollen verkade däremot kunna ge upphov till en kvarvarande moralisk vånda över att de kanske borde ha hjälpt till.

\section{Kompisnormer och sociala hierarkier}

Ytterligare en förklaring till val av åskådarroll var talet om de sociala relationerna. Två typer av sociala relationer lyftes fram: kompisar och sociala hierarkier. En kompis förväntades alltid hjälpa en kompis och eleverna förklarade att de skulle reagera känslomässigt starkare om en kompis blev utsatt. Att hjälpa en kompis förutsattes även om ens kompis var drivande i att mobba någon, vilket kunde leda till moralisk vånda när elever kände sig tvungna att gå med i mobbningen eller förbli passiva trots att de tyckte att mobbningen var fel.

Sociala hierarkier handlade om vem som hade högst status och var mest populär. Högre status än de/den som var drivande i mobbningen kunde göra att eleven ingrep. Lägre status kunde leda till en rädsla att själva drabbas av mobbningen och i sådana situationer förklarade eleverna att de skulle inta en passiv åskådarroll för att skydda sig själva. Den passiva åskådarrollen kunde även här ge upphov till moralisk vånda då eleven kanske egentligen ville hjälpa till men avstod på grund av rädsla.

\section{Att ansvara andra}

Den tredje förklaringen handlande om andra personers ansvar. Två typer av ansvarsförskjutningar lyftes fram: den utsattas roll samt lärare och kamratstödjares roll. Den utsatta gjordes ansvarig genom att beskrivas som orsak till mobbningen genom att definieras som annorlunda eller avvikande. Resonemangen mynnade ut i att eleverna inte skulle ingripa utan förbli passiva eller kanske skulle gå med i mobbningen.

Överförandet av ansvar till lärare och kamratstödjare handlade om att dessa personer ansågs ha en social funktion som gjorde dem mer ansvariga att ingripa. På grund av detta förklarade eleverna att de inte själva hade ett lika stort ansvar att ingripa om lärare eller kamratstödjare fanns tillgängliga. Eleverna förklarade att de i stället skulle inta en passiv åskådarroll.

\section{Avslutning: Agens, vånda och disengagemang}

I elevernas sätt att förklara sitt sätt att reagera som åskådare framträder genomgående den sociala situationens betydelse. I ovan beskrivna förklaringar går det att utläsa tre olika processer som blir avhängiga den sociala situationen: moralisk agens, moralisk vånda och moraliskt disengagemang.

\section{Moralisk agens}

Utifrån elevernas förklaringar uttrycks moralisk agens att ingripa när de:

- Har högre status än den utsatta och är kompis med den utsatta

- Inte anser att någon annan är ansvarig, ex den utsatta

- Bedömer att situationen är allvarlig och att hjälp behövs

\section{Moralisk vånda}

I tidigare studier framkommer att de allra flesta som blir åskådare till mobbning reagerar med en passiv åskådarroll. Vad som är nytt i denna studie är den moraliska vånda som eleverna uttrycker, framförallt när de reagerar med en passiv åskådarroll men hade velat ingripa. Exempel på moralisk 


\section{Venue}

Vol 6 Nr 2 (2017): Tema: Mobbning

Av Forskare

vånda framkommer i situationer när:

- Det är svårt att bedöma allvarlighet och hjälpbehov

- Rädsla uppstår till följd av lägre status än den/de som är drivande i mobbningen

- Eleven går med i mobbningen för att behålla sin kompis

I elevernas förklaringar uttrycks en osäkerhet med att bedöma vad som räknas som allvarligt och vad som räknas som skoj i deras sociala miljö. Det här verkar ibland leda till moralisk vånda där det blir svårt att bedöma om hjälp behövs eller inte. Det blir också tydligt att sociala normer kring vänskap och social status ger upphov till moralisk vånda då eleverna skulle vilja ingripa men inte upplever att de kan.

\section{Moraliskt disengagemang}

Eleverna ger även uttryck för moraliskt disengagemang. Moraliskt disengagemang syftar till att fjärma sig själv ifrån att begå goda handlingar för att i stället agera inhumant utan att känna dåligt samvete (Bandura, 1999). I stället för att ingripa i dessa situationer uttrycker eleverna att de skulle förbli passiva eller ibland till och med gå med i mobbningen när de:

- Gör andra ansvariga, t.ex. den utsatta

- Använder kamratnormer för att avgöra om de ska hjälpa eller inte

- Inte bedömer att situationen är allvarlig

\section{Implikationer}

Utifrån resultaten måste mobbning förstås som ett gruppfenomen där sociala relationer formeras i grupper vilket influerade elevernas åskådaroller. För att motverka moraliskt disengagemang och stärka moralisk agens bör hela gruppen involveras i anti-mobbningsarbetet.

För pedagoger blir det viktigt att höja elevernas medvetenhet om att alla former av mobbning är allvarlig och att ta reda på vilken mobbning som förekommer på den egna skolan. Vidare att därefter diskutera olika typer av mobbning med eleverna, främja empati och sympati för den utsatta och aktivt bygga in viljan att ingripa i anti-mobbningsprogrammen.

Det är även viktigt att diskutera och uppmärksamma elever på grupprocesser som påverkar vem eller vilka de känner lojalitet gentemot och utmana sociala hierarkier genom att medvetet jobba med att stärka positiva relationer mellan elever.

Åskådare som känner moralisk vånda kan potentiellt vara beredda att ingripa och hjälpa en utsatt. En dialog med eleverna om hur moralisk vånda kan hanteras bör initieras med fokus på vad eleverna anser skulle vara behjälpligt om de hamnar i sådana situationer. Moralisk vånda kan även ha negativa hälsoeffekter eftersom eleven fortsätter att ha en kvardröjande känsla av att inte ha reagerat på det sätt eleven hade önskat. 